\title{
YOUNG MAN ON HIS WAY UP: KEOKUK, 1858
}

\author{
By Lida L. Greene \\ Librarian, lowa State Historical Library
}

His name was Rumsey. Israel Parsons Rumsey. He was 21 years old, intent on making his way to the new capital of Iowa at the fork of the Des Moines and Raccoon Rivers, when he came to Keokuk in 1857. His father, Joseph Ellicott Rumsey, seeing no future on the farm for a bright boy, had sent him at 17 to work in the wholesale-retail dry goods business in Buffalo, N. Y. By 1856, young Rumsey had begun to look toward the opening West and its promise. The spring of 1857 found him en route to Muscatine, rails' end beyond the Mississippi.

The story of the young man on his way up returned to Iowa after 110 years. In 1968, Jean Rumsey of Oak Park, IIl., decided to provide her family with a copy of grandfather's memoirs and diary at Christmas. While editing the documents it came to her that here was something descriptive and vital, something worth preserving. Was there a historical society in Des Moines who might like it? She chose Dr. George McCracken, classics professor at Drake University and editor of "The American Genealogist," as her emissary. Last week the Keokuk section of the Rumsey papers arrived at the desk of this librarian. Young Parsons had come back to Iowa.

Spring, 1857, was scarcely an auspicious season to become a new citizen of Iowa. It was a time of financial panic. Banks were closing, business was floundering, the hordes of jobless were growing daily. Farmers in the backlands who depended on the port cities of the Mississippi for what they could not raise were especially hard hit. A wagon load of grain on Main Street, one county history would report, could not buy a bag of flour. This was the April that Rumsey came to Keokuk. 


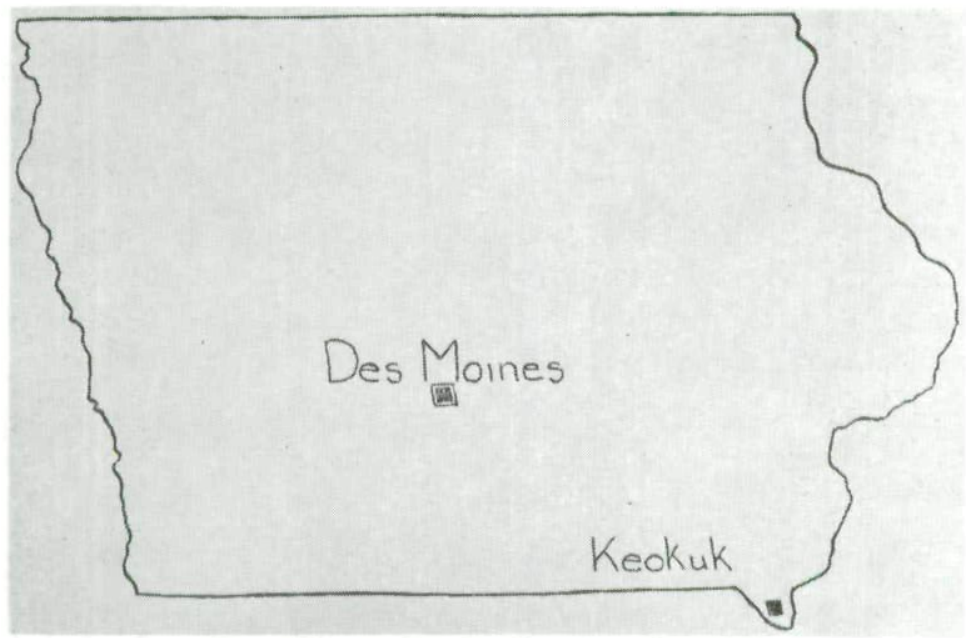

Map of lowa, showing location of Keokuk

Keokuk could scarcely be called a new town. It was 25 years since the Black Hawk War. Before that, it had been the Point or Puck-e-she-tuck, the Indian name for "foot of the falls." A trading post for the American Fur Company, it had a respectable row of hewed $\log$ warehouses and a scattering of cabins among the bluffs that housed agents and traders with Indian wives and growing families of half-breed children. With the Black Hawk Treaty that opened eastern Iowa lands to white settlement, the bands of Sac and Fox Indians moved west along the streams of southern and central Iowa. The trading post followed. The Point became Keokuk, named for the Sac peace chief, and it began to grow. Boats, cargoed for the upper Mississippi, stopped here to lighten their loads over the river rapids. Emigrants by the hundreds passed through on their ways to Dallas County, Salt Lake City or Oregon. Its warehouses held salt pork from Birmingham and Ottumwa alongside glassware and delaine (a woolen or cotton dress fabric) from Cincinnati and Wheeling. By 1857, it was the Gate City with a population of 15,000.

That April, Parsons Rumsey had taken the over-night packet from Muscatine to Keokuk. "Before breakfast," he reported in his 1912 memoirs, "I took a walk through the town, finding large brick buildings, a good sized hotel and large 
wholesale houses. I was especially interested in seeing the prairie schooners drawn by two or more yoke of oxen and hearing the driver crack his whip with a report like a pistol shot. Some were drawn by four horses, the driver riding the high wheel horse with a jerk rein on the leaders. Their harness was the wide strapped kind with breeching at least half a foot wide. These schooners were all freighters coming to this wholesale town for goods . . I immediately decided to remain here and, if a situation could be secured . . to go no further."

That day he made the rounds of dry goods and hardware stores. Owners were affable but discouraging. No business. No hiring. At the river front the boat scheduled to leave for Des Moines in the morning was already crowded with passengers. He heard talk on street corners that more men came back from the new capital than went upriver. It was sobering. That night he slept at the Hitchcock brothers' store. The next day they hired him to work for $\$ 250.00$ a year. Seeing the queues of unemployed in the streets, he knew he should be grateful. At least he had board money.

Within a few months he was job hunting again. Business conditions forced the Hitchcock brothers to dispose of their holdings to an uncle, Robert H. Smith, who lived in the east. Rumsey could not be sure there would be a clerkship for him when the new owner appeared. When he was offered the delivery route for the local Republican newspaper, "The Daily Gate City" (established 1854), he took the job.

After more than 50 years he recalled the experience with zest and humor. "My work consisted of distributing papers every morning from one till seven and collecting the payments from weekly subscribers. I changed my sleeping place to a shed back of the news depot where I shared a bed with the owner of the establishment . By the help of an alarm clock, I arose at one ... I remember yet that particular smell of the printer's ink as I'd go through the printing office after my papers! My only company when I first struck into the street was rats, which I wouldn't even take the trouble to kick off the walk. Taking the first route, which passed by the bakery, there would be first a little yelping dog, then a 
big one would answer and that would set all the dogs in town barking. . It was a caution.

The second route took me over the bluffs of Irish town-a rough part where few Republican newspapers were called for. As I returned . . it would be about daylight and, passing the market, I would stop for a cup of coffee and a doughnut. I then took the third route, through the business portion of town, winding up on the river bank at about seven o'clock . . I still persisted in attending church every Sunday, though you may imagine whether I kept awake after a week of such early hours ..."

The new owner of the Hitchcock store, Robert H. Smith, did want the services of Persons Rumsey. He was rehired at a salary of $\$ 400.00$ a year to manage the hardware concern. He traded his job of delivering "The Daily Gate" to another young man in town, Galloway, a boot and shoe clerk, for $\$ 50.00$ and a silver watch with two dials and a compass. The compass would stand Rumsey in good stead when he served during the Civil War.

The young manager's satisfaction was short-lived. Business was at a stalemate. He spent long hours attempting to make collections on credit sales and trying to find a buyer for the script the community had bcen forced to issue to keep the economy afloat. The year of 1858 brought new troubles. Smith wrote that poor returns from the store necessitated a one-third cut in salary. On Monday, January 25, Rumsey wrote: “. . . I Blue enough and provoked \& mad . . . am yet better off than a good many of my acquaintances. So I will grin \& bare it for the present ..." In early February Smith began to consider moving the stock to Chicago. Mid-March found Rumsey and the Hitchcocks packing for the transfer. On March 19 he set down in his diary: "Hitchcock goods off this morning $\&$ his wife \& Charley are going Monday to Chicago, and we will probly [sic] be off in ten days. (But it won't be we if I could find a situation here in town.)"

The next day, Saturday, he bargained with Messrs. Plummer \& Co. to take over the Smith stock and glass and pocket cutlery. "A good trade," he informed the diary. There was the businessman's note of satisfaction in this entry. 
In the spring of 1858 there seems to have been no new situation in the Gate City for a young man on his way up. After 54 years, Rumsey's daughter was to quote in his memoirs: "We . . . left Keokuk April 12th, the same day I went to Keokuk the year before. I have never been [back] since the day I left ..."

Parsons or I. P. Rumsey later ". . . entered the commission business on the Chicago Board of Trade, enlisted in the army at the start of the Civil War, serving in Battery B, First Illinois Light Artillery . . . with distinction till mustered out with the rank of captain on 12 July 1864." During the war he came across Galloway, his former acquaintance from Keokuk. Galloway was with the 55th Illinois Volunteers en route to Corinth, Miss. Young Galloway did not survive the campaign.

You may wonder why, as we did, that after 54 years, life in Keokuk was still such a sharply etched memory to Parsons Rumsey. Was it because of the silver watch and "poor Galloway" who would never return to the hills on the other side of the Mississippi? Or was it because Rumsey had left a part of his youth in Gate City?

If you have a spare half-hour when you come to visit the Iowa Department of History, you are invited to read the memoirs and diary of Israel Parsons Rumsey. Perhaps these hold the answer, for they are much more than the journal of a young man's vicissitudes during the hard times before the Civil War. They are a part of a city oriented to the river where the arrival of a packet from St. Louis in winter was news on every street corner. They are the slice of another era when entertainment was church sociables, lectures on the grave and humorous at Keokuk College of Physicians and Surgeons, sleighing to the tune of bells and laughter, and even the Irish dance where an unwary guest found himself donating a quarter to pay the fiddler. They are a mirror of the times when newspapers were sharply partisan and a serious young citizen spent Sunday reading the inaugural address of the Hon. Ralph P. Lowe, new governor of the state. 
Copyright of Annals of Iowa is the property of State of Iowa, by \& through the State Historical Society of Iowa and its content may not be copied or emailed to multiple sites or posted to a listserv without the copyright holder's express written permission. However, users may print, download, or email articles for individual use. 